ISSN: 2162-3104 Print / ISSN: 2166-3750 Online Volume 6, Issue 4 (2016), pp. 887-904 (C) Journal of International Students http://jistudents.org/

\title{
Issues of International Students' Academic Adaptation in the ESL Writing Class: A Mixed-Methods Study
}

\author{
Eunjeong Park \\ The Ohio State University, USA
}

\begin{abstract}
Despite the contribution to economic and social impact on the institutions in the United States, international students' academic adaptation has been always challenging. The study investigated international graduate students' academic adaptation scales via a survey questionnaire and explored how international students are academically adapted in the U.S. college setting through qualitative research with class observations, field notes, and semistructured interviews. In addition, the use of lexical bundles was examined as one of the academic literacy adaptation indicators. The quantitative and qualitative results revealed international graduate students' academic adaptation in different angles. The implications of the findings are discussed.
\end{abstract}

Keywords: Academic Adaptation, ESL, International Students, Lexical Bundles, Mixed-methods Research

Open Doors 2015 has released the report of international students studying in the United States. The number of international students at U.S. colleges and universities had the highest rate of growth in 35 years, increasing by ten percent over the prior year in the 2014-2015 academic year. International students constituted approximately $4.8 \%$ enrolled in the total U.S. higher education student population in the year 2014-2015 ("Institute of International Education", 2015). In addition, international students are considered crucial for the economic and social impact on U.S. For instance, they have contributed more than 30.8 billion dollars to the economic vigor of U.S. higher education institutions and their communities and have been dedicated to scientific and technical research and related diverse and 
dynamic perspectives into U.S. classrooms, benefiting American classmates for global careers and business relationships ("Institute of International Education", 2015).

Although the influx of international students has brought great value in the U.S. educational contexts, international students may not be successfully adapted to the target culture and language. Prior research (e.g., Cheng \& Fox, 2008; Spack, 1997) has revealed that international students encounter challenges in their academic adaptation process while studying in a foreign country. Due to the increasing population of international students and their contribution to higher education in the U.S., it is important to explore how the international students studying at colleges and universities in English-speaking countries are adjusted to the target language and culture. As a result, this study examined international graduate students' academic adaptation scales via a survey questionnaire and explored their academic adaptation in the U.S. college setting through qualitative research with class observations, field notes, and semi-structured interviews. To better understand the nature of their language use and help them to improve their English language skills, it is necessary to examine how the students receive the input and yield the output in second language (L2) writing. In this sense, lexical bundles can manifest the degree of academic adaptation through L2 writing. Hence, the research questions are:

1. Which dimension of adaptation is the most challenging for the international graduate students?

2. How do the international graduate students perceive their academic and literacy adaptation in the U.S. university?; 3) What features of lexical bundles can reveal their academic adaptation through second language writing?

\section{LITERATURE REVIEW}

\section{Academic Adaptation}

Prior research (Campbell, 2015; Cheng \& Fox, 2008; Kashima \& Loh, 2006; Kim, 2012; Poyrazli \& Grahame, 2007; Ren, et al., 2007; Spack, 1997; Wadsworth, et al., 2008; Wang \& Mallinckrodt, 2006; Yu \& Downing, 2012; Yuan, 2011) shows a lot of international students encounter challenges in their academic adaptation process while studying in a foreign country. Spack's (1997) longitudinal case study identified inseparability of reading and writing processes in terms of the completion of academic assignments and revealed the participant's strategic way of applying prior developed reading and writing tactics to new course materials, which raises issues about cross-cultural interpretations of student learning. Cheng and Fox (2008) explored how international students were successfully engaged in the academic setting and developed more strategic learning and social 
skills as part of their acculturation process. The results confirmed that academic adaptation is a complex process in an L2 students' intellectual, personal, social, and cultural life and cannot be a one-way transmission from a target community of specialists to novices. Kim (2012) demonstrated and analyzed the process of adaptation by dividing it into four components: a cultural encounter, an experience of obstacles, response generation, and the overcoming phase. Campbell's (2015) phenomenological study examined how international doctoral students acculturate to their new educational settings. Three emerging themes included: the participants' past experiences affecting their desire to study in the U.S.; the participants' interactions within academic and non-academic settings; and the role of family relationships. The study revealed that the students were optimistic about the societal opportunities in the U.S. university, were grateful for the interactions with their instructors, had inadequate relationships with their academic advisers, joined limited social activities outside of academic settings, and made adjustment to family relationships. Campbell (2015) highlighted that the students' educational and cultural backgrounds influenced their decision to study in the U.S. and affected academic acculturation to their new environments.

Based on the literature review above, several terms were adopted. Cheng and Fox (2008) defined academic acculturation as "the dynamic adaptation processes of linguistically and culturally diverse students engaging with the academic study" (p. 309). Morita (2000) pointed out that academic acculturation is a "complex, locally situated process that involves dynamic negotiations of expertise and identity" (p. 304). Various scholars (Kashima \& Loh, 2006; Kim, 2012; Wang \& Mallinckrodt, 2006) defined academic adaptation as a process of appreciation and acquisition of the target culture in an academic situation.

\section{Lexical Bundles as an Indicator of Academic Literacy Adaptation}

For a closer connection with lexicogrammatical awareness, phraseology - the study of fixed expressions and multi-word lexical unitsis one of the fields that SLA (i.e. second language acquisition) and L2 writing researchers have paid attention to in recent years. Early formulaic language-related research emphasized idioms (e.g., kick the bucket, rain cats and dogs) viewed as "archetypical formulaic sequences" (Nekrasova, 2009, p. 648). With the agreement of the statement above, however, some other scholars (e.g., Cowie, 1988; Wray, 2002) have attempted to broaden a definition of an idiom to analyze the whole constructions of writing and argued that the category of formulaic sequences should go beyond conventional idioms and include more transparent constructions of sequential phrases. 
In particular, the research on lexical bundles has been overlooked since traditionally linguists have focused on complete units of grammatical phrases and clauses, rather than lexical units that cut across grammatical structures. Furthermore, lexical bundles have been neglected by linguistics researchers who consider idiomaticity a requirement for language (Conrad $\&$ Biber, 2004). However, Hyland (2008) claims that lexical bundles are a key way of "helping to shape text meanings and contributing to our sense of distinctiveness in a register" (p. 5). Ellis, Simpson-Vlach, and Maynard (2008) maintained that formulaic language provides meaningful educational implications that formulaic language determines learnability and processing fluency.

\section{RESEARCH METHOD}

\section{Research Design}

The study is mixed-methods research via survey research and qualitative research. This study used a mixed method design with a combination of quantitative and qualitative data-more explicitly, the explanatory sequential design (Creswell, 2015). According to Creswell (2015), the purpose of the explanatory sequential design is to initiate a quantitative strand, to implement qualitative research, and to draw inferences for supporting the quantitative results. The research site was the English as a Second Language (ESL) Programs at a large mid-western university. A questionnaire was used for the survey research; semistructured interviews, observations, and field-notes were employed for the qualitative research. Textual analysis was added to examine the participants' writing patterns with regard to lexical bundles.

\section{Sample}

Convenience and purposive sampling was used for this study. The researcher asked the ESL Program Office which composition classes were available as convenience sampling. Then, the classes were selected according to the researcher's criteria (i.e., international graduate students) as purposive sampling. Thirty-five participants in two classes joined the survey research out of the total 36 students. Based on the survey result and the participants' voluntary decisions, three participants were chosen for the qualitative research and the textual analysis.

\section{Instrumentation}

First, a questionnaire was used for the survey research. There are three sub-dimensions of adaptation: sociocultural adaptation, academic and intellectual development/adaptation, and academic adaptation through L2 writing. Statements 1 to 6 are extracted from Ward and Kennedy's (1999) 
measurement study of sociocultural adaptation scale $(r=.85)$. Statements 7 to 13 are selected from one of the subscales is academic and intellectual development $(r=.74)$ in the Pascarella and Terenzini's (1980) study; statements 14 to 20 are related to academic adaptation through L2 writing generated by the researcher.

Second, a semi-structured interview protocol was used for the qualitative research. The question items ask their college lives and academic writing in English in their academic adaptation process as well as demographic information. Since the semi-structured interview was utilized, follow-up questions were added to enrich the description of the participating students' academic adaptation.

Third, the corpus-based text analysis software AntConc (Version 3.4.4) (Anthony, 2015) was employed for investigating lexical bundles. In particular, the function of clusters/N-Grams was utilized to detect the fourword lexical bundles and clarify whether they were not duplicated.

In brief, the data were triangulated with three different dimensions: quantitative, qualitative, and textual. The survey data were used for identifying the most struggle of academic adaptation. Qualitative data were utilized for a deeper understanding of their concerns. Since academic writing was a big concern, the textual analysis was necessary in discovering what specific language features impede the students' academic writing adaptation. Therefore, a variety of the data were triangulated for uncovering the issues of academic adaptation.

\section{Data Analysis}

Descriptive statistics (e.g., mean, standard deviation, frequency, and percentage) and correlation statistics were used for the survey data. Semistructured interview data were analyzed to identify recurring patterns or themes. The final component for the analysis was about lexical bundles. Based on Biber, Johansson, Leech, Conrad, and Finegan's (1999) lexical bundle project, the identification of 4-word lexical bundles has been focused on the analysis of the corpus data since 4-word lexical bundles are more common than 5-word strings and provide a more distinct range of structures and functions than 3-word lexical bundles (Hyland, 2008), holding 3-word bundles in the structure of 4-word strings (Cortes, 2004).

\section{Reliability Estimate of the Surveyed Data}

Reliability of the surveyed data was estimated on the total $(N=35)$ sample. The overall Cronbach's alpha coefficient was .784 for the 20 items. The reliability statistics range indicated a relatively high level of internal consistency and approached those reported in studies with similar populations; namely, Ward and Kennedy's (1999) sociocultural adaptation for part of samples of international student population $(r=.85)$. 


\section{RESULTS}

\section{Results from the Survey Questionnaire}

The survey questionnaires consisted of three dimensions: sociocultural adaptation (Statements 1-6), academic development and adaptation (Statements 7-13), and academic development and adaptation through second language (L2) writing (Statements 14-20). In particular, I borrowed the sociocultural adaptation items from Ward and Kennedy (1999) and academic development and adaptation items from Pascarella and Terenzini (1980). The rest of the items (Statements 14-20) were about academic adaptation through L2 writing, created by the researcher. Descriptive statistics allow researchers to encapsulate the most important properties of the observed data with its average or its degree of variation in order to recognize the typical features of a particular genre (Oakes, 1998). The descriptive statistics of the responses were computed including the means, standard deviations, and percentages (Table 1).

The first dimension aimed at estimating the degree of sociocultural adaptation. The purpose of the questions (Questions 1-6) was to examine international graduate students' sociocultural adaptation especially in the U.S. university. Most students agreed or strongly agreed that they can cope with sociocultural factors at university, such as school regulations and administration (percentage range of answering agree \& strongly agree 88.6$97.1 \%)$. In the first dimension, the most positive response was for Question 1 about following rules and regulations (97.1\%); the least positive response was for Question 6 about expressing ideas in class (88.6\%, see Table 1).

The second dimension was relevant to academic development and adaptation. The questions (Questions 7-13) asked the students about academic adjustment, and the responses varied from question to question (percentage range of answering agree \& strongly agree 51.4-97.1\%). In the second dimension, the most positive response was for Question 10 about the positive influence of academic experiences on intellectual growth and interest in ideas $(97.1 \%$ ); the least positive response was for Question 11 about attending cultural events at the U.S. university (51.4\% see Table 1$)$.

The third dimension asked the students of academic adaptation through L2 writing (Questions 14-20). The responses were yielded with relatively low scores (percentage range of answering agree \& strongly agree 57.2-82.8\%). In the third dimension, the most positive response was for Question 18 about the satisfaction with the academic development of writing $(82.8 \%)$; the least positive response was for Question 20 about the perception of the academic writing adaptation (57.2\% see Table 1$)$.

The survey questionnaire revealed several aspects of international graduate students' adaptation. First, the survey results showed that the students' sociocultural adaptation was higher than academic adaptation and 


\section{Table1: Descriptive Analysis of Survey Responses}

\begin{tabular}{|c|c|c|c|}
\hline Items & $M$ & $S D$ & $\% * *$ \\
\hline 1. I can follow rules and regulations at university. & 2.63 & .547 & 97.1 \\
\hline 2. I can deal with the administration at university. & 2.34 & .591 & 94.3 \\
\hline 3. I can deal with people of higher status at university. & 2.20 & .584 & 91.5 \\
\hline 4. I understand what is required from me at university. & 2.34 & .591 & 94.3 \\
\hline 5. I can cope with academic work. & 2.34 & .591 & 94.3 \\
\hline 6. I can express my ideas in class. & 2.11 & .583 & 88.6 \\
\hline $\begin{array}{l}\text { 7. I am satisfied with the extent of my intellectual } \\
\text { development since enrolling in this university. }\end{array}$ & 2.09 & .507 & 91.4 \\
\hline $\begin{array}{l}\text { 8. I am satisfied with my academic experience at this } \\
\text { university. }\end{array}$ & 1.91 & .612 & 77.2 \\
\hline $\begin{array}{l}\text { 9. Few of my courses this year have been intellectually } \\
\text { stimulating. }\end{array}$ & 1.29 & .710 & 68.6 \\
\hline $\begin{array}{l}\text { 10. My academic experience has had a positive } \\
\text { influence on my intellectual growth and interest in } \\
\text { ideas. }\end{array}$ & 2.34 & .539 & 97.1 \\
\hline $\begin{array}{l}\text { 11. I am more likely to attend academic events now } \\
\text { than I was before coming to this university. }\end{array}$ & 1.51 & .981 & 51.4 \\
\hline $\begin{array}{l}\text { 12. My interest in ideas and intellectual matters has } \\
\text { increased since coming to this university. }\end{array}$ & 2.20 & .584 & 91.0 \\
\hline $\begin{array}{l}\text { 13. I have performed academically as well as I } \\
\text { anticipated I would. }\end{array}$ & 1.86 & .692 & 68.5 \\
\hline $\begin{array}{l}\text { 14. My academic experience at this university has had } \\
\text { a positive influence on my papers in ideas in general. }\end{array}$ & 1.89 & .796 & 68.6 \\
\hline $\begin{array}{l}15 . \text { Most of the courses this year have been involved in } \\
\text { writing assignments accepting the rhetoric from my } \\
\text { home country. }\end{array}$ & 1.74 & .561 & 68.6 \\
\hline $\begin{array}{l}\text { 16. I would like to take more classes where I can } \\
\text { involve my cultural understanding and ideas well } \\
\text { through writing in English. }\end{array}$ & 1.86 & .845 & 62.8 \\
\hline $\begin{array}{l}\text { 17. My interest in writing has increased since coming } \\
\text { to this university. }\end{array}$ & 1.83 & .664 & 68.6 \\
\hline $\begin{array}{l}\text { 18. I am satisfied with the extent of my academic } \\
\text { development in terms of writing a paper at this } \\
\text { university. }\end{array}$ & 1.91 & .612 & 82.8 \\
\hline $\begin{array}{l}\text { 19. I am confident in incorporating my cultural and } \\
\text { academic experiences at this university into my } \\
\text { writing. }\end{array}$ & 1.74 & .561 & 68.6 \\
\hline $\begin{array}{l}\text { 20. I have accomplished a high level of academic } \\
\text { writing adaptation. }\end{array}$ & 1.57 & .608 & 57.2 \\
\hline
\end{tabular}

** Percentage of Responses of "Agree" \& "Strongly Agree" 
academic L2 literacy acculturation. The majority of the participants were positive in the dimension of sociocultural adaptation (93.35\%), while dimensions of academic adaptation and academic L2 literacy adaptation yielded lower percentages $(77.88 \%$ \& $68.17 \%)$ respectively. The international graduate students seemed socially adjusted with the largest percentage among the three dimensions. In other words, they might have conformed to the target culture and society without a lot of difficulties. The students' academic adaptation level was relatively lower than sociocultural adaptation. In particular, students had difficulty in acculturation of L2 writing $(68.17 \%)$.

\section{Table 2: The Average Percentage of the Three Dimensions}

\begin{tabular}{lll}
\hline & Dimension & $\begin{array}{l}\text { Average } \\
\text { Percentage (\%) }\end{array}$ \\
\hline Dimension 1 & Sociocultural adaptation & 93.35 \\
Dimension 2 & Academic development \& adaptation & 77.88 \\
Dimension 3 & $\begin{array}{l}\text { Academic acculturation through second } \\
\text { language writing }\end{array}$ & 68.17 \\
\hline
\end{tabular}

\section{Results from the Semi-structured Interviews and Observations}

The qualitative research revealed individual students' academic acculturation and their challenges of L2 writing. Three participants volunteered to participate in the study, and their demographic information is described in Table 3.

\section{Table 3: Participants’ Demographic Information}

\begin{tabular}{lllllll}
\hline Participant & Gender & Nationality & Age & $\begin{array}{l}\text { Pursuing } \\
\text { Degree }\end{array}$ & $\begin{array}{l}\text { Field of } \\
\text { Study }\end{array}$ & $\begin{array}{l}\text { Years in } \\
\text { the U.S. }\end{array}$ \\
\hline $1^{\text {st }}$ participant & Male & Korean & $30-32$ & $\mathrm{PhD}$ & Architecture & $10 \mathrm{mon}$. \\
$2^{\text {nd }}$ participant & Female & Korean & $27-29$ & $\mathrm{PhD}$ & Nursing & 10 mon. \\
$3^{\text {rd }}$ participant & Female & Korean & $33-35$ & $\mathrm{MA}$ & Education & 10 mon. \\
\hline
\end{tabular}

The three participants showed the diverse degree of academic adaptation and different challenges. For example, one student had an extreme anxiety about language barriers. Thus, he could not participate in adequate courses for his degree because he considered his English proficiency as the most crucial element in his academic path. His satisfaction with the academic adaptation depended on the improvement of the English language. Language is no doubt a necessary condition for learning in a foreign country. However, he struggled a lot with his low level of English, which has impeded his intellectual and academic development and adaptation. The second student had a different acculturative curve. Her sociocultural adaptation did not seem to be smooth due to her academic environment. She considered that the department plays a crucial role for the international 
students' adaptation. Due to insufficient academic orientations, she consistently answered items about regulations, requirements, and administrators in a university with negativity. From the results of the survey, observations, and interviews, she encountered challenges of sociocultural adaptation.

The interviews with the participants revealed that their challenges of L2 writing were a big issue to be specified. The participants' challenges of L2 writing are described individually. The first participant encountered mainly two issues. The first problem was generally how he organizes or outlines academic papers aligned with the intent of the writing genre, such as annotated bibliographies and critical literature reviews.

For the annotated bibliography, I didn't know how to reduce the literatures into one paper. [For the critical review] I didn't know how to express my opinions about the literatures. That was the serious problem for me. But, in the class, the instructor introduced some methods and fixed my problem...I didn't know about [the verb usage]; I mean how to explain and how to express my opinions about the literatures. I think a verb [contains] the main idea of sentences. For example, I agree with the opinion, but I don't know how I can express [the agreement] by [using] other words. So, that is the problem in the annotated bibliography (the $2^{\text {nd }}$ interview, 05/29/15).

The second problem was more relevant to local issues, like the verb usage:

We do not learn how to think or how to write about my thoughts in Korea. At the first time when I wrote the paper, it was very difficult [because] I didn't know how to explain and how to organize my thoughts. It's hard to describe my thoughts in detail in English. I think it is the most [difficult]. For me, the critical review paper was more challenging because I need to find some similarities and differences between two articles, analyze both of them, and relate them (the $1^{\text {st }}$ interview, 04/01/15).

The second participant's challenge came along with the organization of ideas in writing. She specified that she had a hard time composing the critical review paper due to the difficulty that she encountered with regard to the structure of the academic writing:

I think that an idea is more important than a language. I think if I have a good idea, I can find the way to write [although] it's not a good quality. But, if I have no idea, I can't write anything. Even if we learn how to write, ideas-what we want to talk about the topic-are 
so important... The most difficulty [in the writing class] is we have to find evidence. The professor always thinks that when we argue with something, we have to use the evidence from our experience $(04 / 08 / 15)$.

While the first participant struggled with language issues and the second participant with sociocultural adaptation, the third participant's academic adaptation was hindered due to innovative ideas in writing. She argued that language may not be an issue of her academic writing. Rather, she was concerned about ideas and thoughts to generate good quality of writing. She expressed different challenges of academic adaptation through L2 writing, such as finding scholarly evidence, because she considered that appropriate evidence by scholarly references results in good quality of academic writing.

\section{The Use of Lexical Bundles as the Indicator of Academic Literacy Adaptation}

To examine the participants' academic literacy adaptation, lexical bundles were examined through their writing. Hyland (2008) and Leki (2007) claimed that being adapted to the expectation of academic writing and rhetoric enables learners to gain membership in the involved community. Two features of lexical bundles - structural and functionalwere analyzed based on Biber et al.’s (1999) ancestral research.

\section{Structural characteristics of lexical bundles}

Figure 1 shows the proportions of structural patterns in graduate international students' writing, compared to the ones in academic prose in Biber et al.'s (1999) project. Major structural patterns in Biber et al.'s project are noun phrases $(32 \%)$ and preposition with noun phrase fragments (33\%). The present study disclosed a somewhat different trend from Biber et al.'s work, with 67 percent of noun phrases, taking up two-thirds of the entire bundles; 17 percent of preposition with noun phrase fragments. Another main structural pattern displayed in international students' writing is content-focused compound noun phrases, containing two or more words to make a single noun with 23 percent. It can be assumed that the reason for using a large portion of noun phrases and compound noun phrases would be the register type. The writing samples used in this study are all critical review papers. Thus, the writing samples tend to exhibit information from previous literature. Furthermore, specific disciplines (i.e., architecture \& nursing) employ technical terms very frequently, such as 'the cell cycle regulation' with frequency counts of 15 . Other structural patterns, such as anticipatory it $+\mathrm{VP} /$-adjective phrase ( + complement clause) and passive verb + prepositional phrase fragment, have a similar trend to Biber et al.'s 
patterns. The rest of the three structural patterns, such as pronoun/NP (+ auxiliary) + copular be $(+)$, (verb +$)$ that-clause fragment, and (verb/adjective + ) to-clause fragment, are not found in the students' samples. This would be because the written register is limited to only critical reviews, and the sample size is very small - three critical review papers with 12,941 word tokens. Biber et al. (1999) do not specify frequency counts of structural patterns, so percentage data are employed in Figure 2. Compared to academic prose in Biber et al., nouns are much more common than other parts of speech (i.e., adjectives and verbs) in the students' writing samples. Nouns are the most frequently used patterns, reflecting that the written registers pursue the primary informational purposes of writing-critical reviews.

\section{Figure 1: Percentage Distribution of Structural Characteristics between Academic Prose and Participants' Writing Samples}

\section{Biber et al. (1999) $\quad$ Sampled Writing}

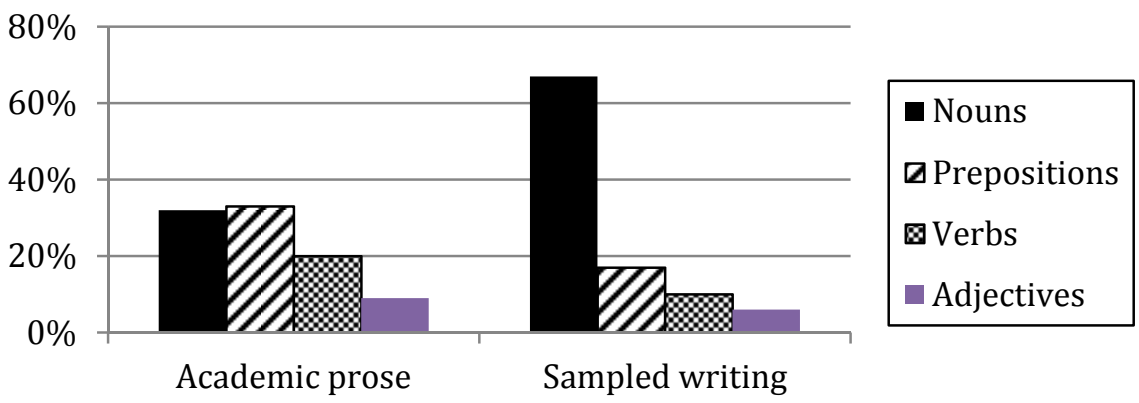

Functional characteristics of lexical bundles

About 40 percent of the functional use was revealed in the students' written register in the preliminary findings. Biber et al. (1999) highlighted three primary functions of lexical bundles in the registers: 1) stance bundles, 2 ) discourse organizers, and 3) referential bundles. However, two types of functions (i.e., stance and referential bundles) were found in the study. Attitude/modality stance bundle, specifically with an obligation function, takes up 6.48 percent with seven frequency counts (e.g., it is necessary to). Referential bundles with the function of place occupy 12.04 percent with 13 frequency counts (e.g., in the cell cycle); referential bundles with tangible framing attributes take up 21.30 percent with 23 frequency counts (e.g., the impact of urban form, the development of PTSD, phenomenon of post ICUPTSD). The rest of lexical bundles with 60.18 percent are all contentoriented combinations. For example, the most frequent bundle is 'the cell cycle regulation' with 15 frequency counts $(13.89 \%)$. However, 'the cell 
cycle regulation' is a technical term in the nursing discipline regardless of any lexical functions. Therefore, the analysis reveals that when international graduate students write critical reviews, they tend to use a lot of technical terms from the previous literature focusing on unique disciplines.

Table 4: The Summary Table of Lexical Bundles in the Corpus of the Final Papers

\begin{tabular}{|c|c|c|c|c|}
\hline Lexical bundles & $S$ & Function & $F$ & $\%$ \\
\hline the cell cycle regulation & NP & Content & 15 & 13.88 \\
\hline in the cell cycle & PP & Referential-place & 13 & 12.04 \\
\hline impact(s) on travel behavior & NP & Content & 11 & 10.18 \\
\hline impact of urban form & NP & $\begin{array}{l}\text { Referential- } \\
\text { framing attributes }\end{array}$ & 9 & 8.33 \\
\hline the development of PTSD & NP & $\begin{array}{l}\text { Referential- } \\
\text { framing attributes }\end{array}$ & 8 & 7.41 \\
\hline form on travel behavior & NP & Content & 7 & 6.48 \\
\hline it is necessary to & AP & Stance- obligation & 7 & 6.48 \\
\hline involved in the cell & VP & Content & 6 & 5.56 \\
\hline of the cell cycle & PP & Content & 6 & 5.56 \\
\hline phenomenon of post ICU-PTSD & NP & $\begin{array}{l}\text { Referential- } \\
\text { framing attributes }\end{array}$ & 6 & 5.56 \\
\hline $\mathrm{RB} / \mathrm{E} 2 \mathrm{~F}$ pathway and dream & NP & Content & 5 & 4.63 \\
\hline $\begin{array}{l}\text { complex } \\
\text { of the development of }\end{array}$ & DD & Content & 5 & 163 \\
\hline solve the problem of & VP & Content & 5 & 4.63 \\
\hline $\begin{array}{l}\text { three argumentative organizational } \\
\text { plans }\end{array}$ & NP & Content & 5 & 4.63 \\
\hline Total count & 14 & & 108 & 100 \\
\hline
\end{tabular}

Total word tokens: 12,941

Note: $\mathrm{F}=$ Frequency, $\mathrm{S}=$ Structure

\section{DISCUSSION AND CONCLUSIONS}

Three main topics are discussed from quantitative survey findings, qualitative semi-structured interview results, and the textual analysis of lexical bundles.

\section{Academic Adaptation from the Survey Results}

First, the survey data yielded two themes: difficulty in academic adaptation through L2 writing and the relationship between perceived 
English proficiency and L2 writing. The survey questionnaire investigated three sub-dimensions - sociocultural adaptation, academic adaptation, and academic adaptation through L2 writing. The majority of the graduate international students are socially adjusted (93.35\%), while dimensions of academic adaptation and academic L2 literacy adaptation yielded lower percentages $(77.88 \% \& 68.17 \%)$ respectively. In other words, they tend to conform to culture and society without a lot of difficulties. The students' academic adaptation level is relatively lower than sociocultural adaptation. In particular, students have difficulty in academic adaptation of L2 writing (68.17\%). According to Angelova and Riazantseva's (1999) study, international students have all the attitudinal, cognitive, and social problems. Cheng and Fox (2008) argued that academic acculturation is a complex process in an L2 students' intellectual, personal, social, and cultural life and cannot be a one-way transmission from a target community of specialists to novices. Therefore, although sociocultural adaptation does not seem to be problematic for the participants, it is necessary to carefully observe their adaptation with various angles-sociocultural, general academic and literacy-based academic.

The other important feature has been found in students' perceived English language proficiency. The students' perceived comfort of using English was statistically significantly correlated with academic adaptation ( $p$ $<.05$ ). The results may indicate that the students' comfortableness of English influences their academic adaptation in the U.S. university. That is, as the students become comfortable with the English language, the academic adaptation becomes smoother. Their perceived communication level was also statistically significantly correlated with academic adaptation through L2 writing $(p<.05)$. Hence, the perceived communication level may be critical in their L2 writing in the adaptation process. In other words, students perceive writing as a medium of communication. Proficient communication may improve L2 writing, which means that the students may recognize the audience in writing. As Spack (1997) revealed that the participant's educational background shaped the approach to U.S. academic discourse practices and the way she theorized about U.S. rhetoric, the findings confirmed that the international students' perceived English proficiency as one of the background components influences their academic adaptation. In addition, the findings are quite significant because this is connected to the third topic of lexical bundles.

\section{Academic Acculturation in the L2 Writing Class}

The second main issue is academic acculturation generated from the qualitative findings of semi-structured interviews, class observations, and field notes. Survey results showed that academic acculturation through second language writing was the most challenging $(68.17 \%)$. The 
qualitative findings confirmed that academic writing is the major concern of the international students. Among the three participants, two participants' responses offered some meaningful aspects of academic acculturation. The first participant's hardship of academic acculturation resulted from the mismatched expectation and a language barrier. Cheng and Fox (2008) also claimed that the issue of mismatched agendas leads to the difficulty in academic adaptation. Students' expectations and needs sometimes do not meet the ones within the university. His lack of confidence in English is matched to the lower level of academic adaptation and acculturation through writing. His sociocultural adaptation level was comparatively better than academic adaptation. He attributed the lack of academic adaptation to English language proficiency. On the other hand, the second participant's low sociocultural adaptation level contradicted the entire survey results. The second participant's difficulty in sociocultural adaptation is attributed to her contextual barrier. A fair indication can be that a low level of sociocultural adaptation usually gets recovered as time flows. The second participant's subsequent interview also suggested that her responses of Dimension 1 (i.e., sociocultural adaptation) have been changed more positively. To sum up, the most crucial factor of improving academic acculturation is still an adequate level of language proficiency in the academic setting. Angelova and Riazantseva's (1999) study supported the findings that international students, who possess different writing experiences from diverse linguistic and cultural backgrounds, need assistance to more easily adapt to the new academic repertoire. Campbell's (2015) phenomenological study also suggested that international students' educational and cultural backgrounds influence academic acculturation to their new environments. Hence, it is necessary to examine how they attempt to acquire English to be smoothly acculturated in the U.S. university.

Class observations and field notes discovered international students' L2 academic disciplinary power into learning and teaching practices in the classroom. This disciplinary power may conflict with Leki's (2007) argument about the mismatch of ESL composition courses and students' experiences of academic literacy. The first participant had linguistic challenges in the class, particularly the verb usage connected to formulaic language functions. When the first participant expressed his difficulty to the instructor, the instructor showed a new strategy to use Word \& Phrase INFO in the COCA (Corpus of Contemporary American English) corpus reference tool to the students with one example paper. This instructional adjustment was confirmed by Fujioka's (2014) argument about "changes and transformations the writer brought to himself, his writing practices, his professor, and the social practices in his community" (p. 55). The first participant's rigorous class participation stimulated the instructors' 
willingness to modify teaching practices, which ultimately contributed to the first participant's improved writing practices.

Without doubt, corpus-based instruction with the COCA (Corpus of Contemporary American English) has been proved to be effective in enhancing students' academic acculturation. Yoon and Hirvela's (2004) study revealed that the students perceived the corpus approach as beneficial to the development of L2 writing skill and increased confidence toward L2 investigation of attitudes toward corpus-based writing instruction. Similarly, most students seemed to be satisfied with using corpus data in the advanced academic writing class. Different resources, such as the instructor's feedback and tutorials, gradually challenging assignments, and peer-editing, would be also helpful. Since the advance of technology, students have heavily depended on computer-generated information. The corpus engagement in composition must be a necessary condition to provide effective instruction of especially L2 writing.

\section{Lexical Bundles as an Indicator of Academic Literacy Adaptation}

The investigation of lexical bundles is essential in finding out whether a relationship between academic adaptation and lexical bundles exists. In other words, the use of lexical bundles can be an indicator of the improvement on international students' academic literacy adaptation. Structural and functional components are the two characteristics of lexical bundles by Biber et al.'s (1999) study. In terms of structural features, the participants' lexical bundles are found to follow the trend of the most frequent used noun phrase fragments from Biber et al.'s (1999) work. In particular, content-focused compound noun phrases are most frequently used due to the special written register, such as critical reviews. The functional use of lexical bundles was not represented as meaningful in the findings due to the small sample size. However, it turns out that the students do not seem to express their own voices in critical reviews. Rather, they tend to write carefully not to misconstrue the original articles. To make this pilot study meaningful, it is necessary to accumulate writing samples in the corpus for significant contributions to the corpus research.

\section{LIMITATIONS}

This study has several limitations that need to be addressed for enhancing future research. First, due to the small sample size $(N=35)$, the results cannot be generalizable, and the corpus data was too small to be analyzed or interpreted. Second, validity would be another limitation. The survey questionnaire items were not factor-analyzed for validity. Finally, although the researcher took field notes during the observations in the classrooms, little information of field notes was used for analyzing and interpreting the 
participants' behaviors and attitudes regarding academic adaptation, and the phenomena of the classroom.

\section{IMPLICATIONS}

This study provided a picture of the international students' academic adaptation by incorporating different research methods-survey, semistructured interviews, observations, and a textual analysis. The research also offered potentials for researchers to implement mixed-methods research in order to enrich research about academic adaptation with various researchbased evidences. Future research needs more improvement. First, more samples are necessary in developing valid and reliable survey research so that the results can be representative and generalizable. L2 writing samples should be accumulated for significant contributions to the corpus research. Furthermore, examining different genres of writing and registers (i.e., spoken and written) would provide a lot clearer essence of lexical bundles in L2 writing. As Sánchez Hernández' (2013) study suggested, a simple exposure to lexical bundles may not lead to the acquisition or mastery of the formulaic expressions by international students. Hence, my future research will connect the information and knowledge of lexical bundles to L2 learning instruction and pedagogy. In light of qualitative case studies, various research techniques, such as field notes, interviews, and verbal protocols, should be practically employed for yielding valuable findings. In order to do this, the researcher should learn effective ways to conduct qualitative case studies by rigorously reading research-relevant prior studies and theoretical pieces of writing.

\section{REFERENCES}

Anthony, L. (2015). AntConc (Version 3.4.4) [Computer Software]. Tokyo, Japan: Waseda University. Available from http://www.laurenceanthony.net/

Bal, B. (2010). Analysis of four-word lexical bundles in published research articles written by Turkish scholars (Unpublished master's thesis). Georgia State University, Atlanta, GA. Retrieved from http://scholarworks.gsu.edu/alesl_theses/2

Biber, D., Johansson, S., Leech, G., Conrad, S., \& Finegan, E. (1999). Longman grammar of spoken and written English. London: Pearson.

Campbell, T. A. (2015). A phenomenological study on international doctoral students' acculturation experiences at a U.S. university. Journal of International Students, 5(3), 285-299.

Cheng, L., \& Fox, J. (2008). Towards a better understanding of academic acculturation: Second language students in Canadian Universities. Canadian Modern Language Review, 65(2), 307-333.

Conrad, S., \& Biber, D. (2004). The frequency and use of lexical bundles in conversation and academic prose. Lexicographica, 20, 56-71. 
Cortes, V. (2004). Lexical bundles in published and student disciplinary writing: Examples from history and biology. English for Specific Purposes, 23, 397-423.

Cowie, A. (1998). Phraseology: Theory, analysis and applications. Oxford: Oxford University Press.

Creswell, J. W. (2015). A concise introduction to mixed methods research. Thousand Oaks, CA: SAGE Publications, Inc.

Ellis, N. C., Simpson-Vlach, R., \& Maynard, C. (2008). Formulaic language in native and second language speakers: Psycholinguistics, corpus linguistics, and TESOL. TESOL Quarterly, 42(3), 375-396.

Fujioka, M. (2014). L2 student-U.S. professor interactions through disciplinary writing assignments: An activity theory perspective. Journal of Second Language Writing, 25, 40-58.

Hyland, K. (2008). As can be seen: Lexical bundles and disciplinary variation. English for Specific Purposes, 27, 4-21.

Institute of International Education. (2015). Open doors 2015: International students. Retrieved from http://www.iie.org/opendoors

Kashima, E. S. \& Loh, E. (2006). International students' acculturation: Effects of international, conational, and local ties and need for closure. International Journal of Intercultural Relations, 30, 471-485.

Kim, J. (2012). The birth of academic subalterns: How do foreign students embody the global hegemony of American universities? Journal of Studies in International Education, 16(5), 455-476. doi: 10.1177/1028315311407510

Leki, I. (2007). Undergraduates in a second language: Challenges and complexities of academic literacy development. Mahwah, $\mathrm{NJ}$ : Lawrence Erlbaum.

Morita, N. (2000). Discourse socialization through oral classroom activities in a TESL graduate program. TESOL Quarterly, 34, 279-310.

Nekrasova, T. M. (2009). English L1 and L2 speakers' knowledge of lexical bundles. Language Learning, 59(3), 647-686.

Oakes, M. P. (1998). Statistics for corpus linguistics. Edinburgh: Edinburgh University Press.

Pascarella, E. T., \& Terenzini, P. T. (1980). Predicting freshman persistence and voluntary dropout decisions from a theoretical model. The Journal of Higher Education, 51(1), 60-75.

Poyrazli, S., \& Grahame, K. M. (2007). Barriers to adjustment: Needs of international students within a semi-urban campus community. Journal of Instructional Psychology, 34(1), 28-45.

Ren, J., Bryan, K., Min, Y., \& Wei, Y. (2007). Language preparation and the first year experience: What administrators and policy makers should know. Florida Journal of Educational Administration \& Policy, 1(1), 11-24.

Sánchez Hernández, P. (2013). Lexical bundles in three oral corpora of university students. Nordic Journal of English Studies, 13(1), 187-209.

Spack, R. (1997). The acquisition of academic literacy in a second language: A longitudinal case study. Written Communication, 14(1), 3-62.

Wadsworth, B. C., Hecht, M. L., \& Jung, E. (2008). The role of identity gaps, discrimination, and acculturation in international students' educational satisfaction in American classrooms. Communication Education, 57(1), 64-87. 
Wang, C., \& Mallinckrodt, B. (2006). Acculturation, attachment, and psychosocial adjustment of Chinese/Taiwanese international students. Journal of Counseling Psychology, 53(4), 422-433.

Ward. C, \& Kennedy, A. (1999). Sociocultural Adaptation Scale [Measurement instrument]. Retrieved from http://psycnet.apa.org/index

Wray, A. (2002). Formulaic language and the lexicon. Cambridge: Cambridge University Press.

Yu, B., \& Downing, K. (2012). Determinants of international students' adaptation: examining effects of integrative motivation, instrumental motivation and second language proficiency. Educational Studies, 38(4), 457-471. http://dx.doi.org/10.1080/03055698.2011.643111

Yuan, W. (2011). Academic and cultural experiences of Chinese students at an American university: A qualitative study. Intercultural Communication Studies, 20(1), 141-157.

EUNJEONG PARK is a PhD candidate in Teaching and Learning at The Ohio State University, specializing in Foreign and Second Language Education. Her research and teaching interests include second language writing, corpus research, and mixed-methods research. Email: park.1752@osu.edu 